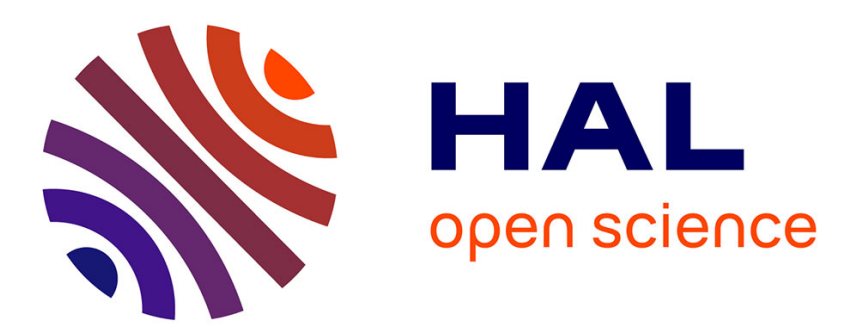

\title{
Design of polymeric capsules for self-healing concrete
} Benoit Hilloulin, Kim van Tittelboom, Elke Gruyaert, Nele de Belie, Ahmed Loukili

\section{To cite this version:}

Benoit Hilloulin, Kim van Tittelboom, Elke Gruyaert, Nele de Belie, Ahmed Loukili. Design of polymeric capsules for self-healing concrete. Cement and Concrete Composites, 2015, 55, pp.298-307. 10.1016/j.cemconcomp.2014.09.022 . hal-02179977

\section{HAL Id: hal-02179977 \\ https://hal.science/hal-02179977}

Submitted on 12 Jul 2019

HAL is a multi-disciplinary open access archive for the deposit and dissemination of scientific research documents, whether they are published or not. The documents may come from teaching and research institutions in France or abroad, or from public or private research centers.
L'archive ouverte pluridisciplinaire HAL, est destinée au dépôt et à la diffusion de documents scientifiques de niveau recherche, publiés ou non, émanant des établissements d'enseignement et de recherche français ou étrangers, des laboratoires publics ou privés. 


\section{Design of polymeric capsules for self-healing concrete}

2

3

4

\section{Abstract}

14 Up to now, glass capsules, which cannot resist the mixing process of concrete, have life of encapsulated adhesives, this seems to be a promising route.

$$
\text { Benoit Hilloulin }{ }^{\mathrm{a}, \mathrm{b}^{*}} \text {, Kim Van Tittelboom }{ }^{\mathrm{b}} \text {, Elke Gruyaert }{ }^{\mathrm{b}} \text {, }
$$
Nele De Belie ${ }^{\mathrm{b}}$, Ahmed Loukili ${ }^{\mathrm{a}}$

${ }^{a}$ LUNAM Université, Institut de Recherche en Génie Civil et Mécanique (GeM), UMR-CNRS 6183, Ecole Centrale de Nantes, 1 rue de la Noë, 44321 Nantes, France - e-mail: benoit.hilloulin@ec-nantes.fr; ahmed.loukili@ec-nantes.fr

${ }^{b}$ Magnel Laboratory for Concrete Research, Department of Structural Engineering, Faculty of Engineering, Ghent University, Technologiepark Zwijnaarde 904, B-9052 Ghent, Belgium - email: Kim.VanTittelboom@ugent.be, Elke.Gruyaert@ugent.be, Nele.DeBelie@ugent.be

* Corresponding author: Tel.: + 33 (0)2 40371663

been mostly used in lab-scale proof-of-concept to encapsulate polymeric agents in selfhealing concrete. This study presents the design of polymeric capsules which are able to resist

the concrete mixing process and which can break when cracks appear. Three different polymers with a low glass transition temperature $\mathrm{T}_{\mathrm{g}}$ have been extruded: Poly(lactic acid $\quad(\mathrm{PLA}) \quad\left(\mathrm{T}_{\mathrm{g}}=59^{\circ} \mathrm{C}\right), \quad$ Polystyrene $\quad(\mathrm{PS}) \quad\left(\mathrm{Tg}=102{ }^{\circ} \mathrm{C}\right) \quad$ and Poly(methyl methacrylate/n-butyl methacrylate) $(\mathrm{P}(\mathrm{MMA} / \mathrm{n}-\mathrm{BMA}))\left(\mathrm{Tg}=59^{\circ} \mathrm{C}\right)$. After heating the capsules prior to mixing with other components of the mix, to shift from a brittle state to a rubbery state, their survival ratio considerably increased. Moreover, a part of the capsules, which previously survived the concrete mixing process, broke with crack appearance. Although some optimization is still necessary concerning functional 27 
Keywords: Self-healing Concrete, Polymers, Capsules, Mixing, Mortar, Cracks

\section{Introduction}

In concrete structures, cracks often appear due to the limited tensile strength of concrete.

These cracks endanger the durability as aggressive substances, dissolved in fluids and gasses, can easily flow inside the matrix and lead to structural failure by reinforcement corrosion. Moreover, cracks are also considered undesirable for aesthetic reasons. Due to regular and planned inspection rounds followed by proper treatments, maintenance costs of concrete structures are quite high nowadays. It has been estimated that, in Europe, around $50 \%$ of the annual construction budget is spent on rehabilitation and repair of the existing structures $[1,2]$.

Therefore, making self-healing concrete could highly reduce the maintenance costs and

41 improve the durability of concrete structures. Under control, self-healing could be taken into account by designers to meet project owners' durability expectations, following the

43 'damage management concept' introduced by Van der Zwaag in opposition to the actual

44 'damage prevention principle' widely used in construction codes [3]. Consequently, service life of structures would increase considerably.

Encapsulation of healing agents is a very effective method to obtain complete sealing of

47 the crack with chemical agents, to avoid penetration of aggressive substances and, in some cases to obtain partial regain in mechanical properties which is an important aspect to guarantee the performance during service life (succession of crack formations)

50 [4]. However, up to now, glass capsules have been mostly used [5-11] to store the

51 healing agent. They break upon crack appearance but they cannot resist the concrete mixing process without particular protection (protection by a cement paste bar or a 
metallic wire seem limited $[12,13]$, only bundling the capsules with a water soluble

54 solution is reported to protect them while mixing in a truck [14]). This can be explained by their brittleness and their dimensions (glass tubes with a wall thickness of $2 \mathrm{~mm}$ are able to rupture upon crack formation, $3 \mathrm{~mm}$ thick tubes cannot break any more upon crack formation [15]. Survival of the concrete mixing process would facilitate the application of self-healing materials and decrease their price by reducing human work. An evolution towards polymeric encapsulation materials could be the means to adjust capsule properties more easily and to resist the mixing process (as suggested by Dry [16]). Besides glass, some natural fibres [17, 18], gelatine capsules [1], paraffin to enclose water [19], wax [20] and polyurethane [21] have been used. Ceramic, a very brittle material, has also been used by Van Tittelboom [4] who observed a better bond strength than with glass. Spherical capsules can be successfully mixed in concrete [1, 20-26] but cylindrical capsules present better chances to break upon crack appearance [13] and release the healing agent more efficiently [27] even if their orientation is still a concern. Polypropylene capsules coated with wax and heated to release the capsules content [8] have been studied to produce capsules able to resist the concrete mixing process.

This study explores the development of polymeric capsules that are able to survive the concrete mixing process without any particular protection, and to break upon crack appearance without human intervention. The selected polymers are brittle at room temperature and have a relatively low glass transition temperature. Consequently, their ability to resist the concrete mixing process, when they were heated before mixing and mixed with heated components, was studied. The capsule breakage with crack appearance was measured by the means of three-point-bending tests performed on small mortar specimens. 
2. Materials and methods

\subsection{Materials preparation}

\subsubsection{Extrusion of the capsules}

83 In order to be able to change easily the mechanical properties of the capsules, polymers

84 with low glass transition temperatures have been selected. Indeed, around their glass transition temperature, the physical properties of polymers change considerably. At first, polymers with a glass transition temperature between $35^{\circ} \mathrm{C}$ and $50{ }^{\circ} \mathrm{C}$ were sought for.

Later, this range was extended until $100{ }^{\circ} \mathrm{C}$ to include cheaper and more common materials. On the other hand, specific attention was paid to select polymeric materials with a relatively brittle behaviour at room temperature (low elongation at rupture, relatively high tensile strength). The permeability of the polymers was also taken into account because it may influence the shelf-life of the healing agent embedded inside the

92 polymeric capsules.

93 Finally, three polymers have been selected:

94 - Poly(lactic acid) (PLA) is derived from renewable resources (sugar cane, corn, tapioca) and is biodegradable. It has a low $\mathrm{T}_{\mathrm{g}}\left(\right.$ around $60{ }^{\circ} \mathrm{C}$ ) and can break at limited elongation (1 to $10 \%)$. PLA is largely used in food industry to replace polystyrene but exhibits a

97 relatively high water-vapour transmission rate [28-31]. No application of PLA in 98 concrete or buildings materials is known by the authors.

99 - Polystyrene (PS) is a common plastic known for its brittleness (elongation at rupture 100 inferior to $2 \%$ ) and its good chemical resistance as it is used for food packaging. It is cheap but its $\mathrm{T}_{\mathrm{g}}$ comes close to $100{ }^{\circ} \mathrm{C}$. Its permeation properties are relatively good and 
102 close to the ones of PLA [32]. Expanded polystyrene is used as aggregate in place of

103 sand and stone in lightweight concrete [33-36].

104 - Poly(methyl methacrylate/n-butyl methacrylate) (called P(MMA/n-BMA) in this study)

105 with a catalogued $\mathrm{T}_{\mathrm{g}}$ of $50^{\circ} \mathrm{C}$. It has been considered in this study because of the 106 brittleness of Poly(Methyl Methacrylate) and the low $T_{g}$ of $P(M M A / n-B M A)\left(\right.$ while $T_{g}$

107 of pure PMMA is around $105^{\circ} \mathrm{C}$ ). Although pure PMMA has been compared to

108 concrete because of its brittle behaviour [37] and has been incorporated as a waste

109 material in asphalt mixes, no other application of $\mathrm{P}(\mathrm{MMA} / \mathrm{n}-\mathrm{BMA})$ in civil engineering

110 is known by the authors [38-40].

111 A laboratory-scale inter-meshing co-rotating twin-screw extruder (MP19TC-25, APV

112 Baker, Newcastle-under-Lyme, UK) with a length over screw diameter ratio (L/D) of

113 25:1 was employed to extrude hollow tubes using a die with an outer hole of diameter 5

$114 \mathrm{~mm}$ and an inner pin of diameter $3 \mathrm{~mm}$. The temperature settings used during the

115 extrusion process to obtain a good melt without degradation, are presented in Table 1.

117 Table 1: Temperature settings $\left({ }^{\circ} \mathrm{C}\right)$ at several locations in the extruder for extrusion of

118 the different thermoplastics.

\begin{tabular}{|c|c|c|c|c|c|}
\hline Polymer & $\begin{array}{c}\text { T1 } \\
\text { (breaker plate) }\end{array}$ & T2 & T3 & T4 & $\begin{array}{c}\text { T5 } \\
\text { (entrance of the barrel) }\end{array}$ \\
\hline PLA & 135 & 148 & 152 & 150 & 145 \\
\hline P(MMA/n-BMA) & 127 & 131 & 130 & 130 & 123 \\
\hline PS & 178 & 171 & 165 & 160 & 150 \\
\hline
\end{tabular}

120 Different sizes of tubes were obtained due to different expansion ratios of the polymers.

121 Along the same tube of a length of 1 meter, the thickness and the diameter also varied.

122 Hollow tubes were cut at $5 \mathrm{~cm}$ length or $10 \mathrm{~cm}$ length for the different tests. Capsules

123 were sorted in different size ranges and their cross section area was measured by means 
124 of a light microscope. The mean values of the measured sizes are presented in Table 2

125 (standard deviation which was relatively small (maximum $0.2 \mathrm{~mm}$ ) is not mentioned).

126 As PS capsules had almost all the same dimensions, they were not sorted. Rods were

127 also extruded with dies with holes of $1.8 \mathrm{~mm}$ and $4.9 \mathrm{~mm}$ to perform dynamic

128 mechanical analysis (DMA).

130 Table 2: Approximate dimensions of extruded capsules for the different size ranges

131 (mean values of the outer diameter [mm] and the inner diameter [mm]).

\begin{tabular}{|c|c|c|c|c|c|}
\hline Polymer & S1 & S2 & S3 & S4 & S5 \\
\hline PLA & $1.9,1.1$ & $3.5,1.8$ & $4.0,2.1$ & $4.5,2.6$ & $5.2,3.2$ \\
\hline P(MMA/n-BMA) & $6.0,3.3$ & $6.4,3.4$ & $6.6,3.6$ & $6.7,3.8$ & $6.8,4.0$ \\
\hline PS & \multicolumn{5}{|c}{$7.2,3.8$} \\
\end{tabular}

132

133 PLA, P(MMA/n-BMA) and PS have been successfully extruded with a relatively wide

134 range of temperature settings $\left( \pm 5^{\circ} \mathrm{C}\right.$ in values specified in Table 1 can also lead to a successful extrusion) and no sign of degradation.

\subsubsection{Preparation of the mortar samples}

138 Bond strength test and three points bending test have been performed to show the

139 interest of polymeric capsules in self-healing concrete.

140 Bond strength tests have been performed in order to ensure that the capsules would not

141 slip in the concrete matrix during crack formation. To measure the bond strength, $5 \mathrm{~cm}$

142 long polymeric tubes filled with epoxy were partially embedded (10 mm) inside mortar

143 samples $(\mathrm{W} / \mathrm{C}=0.5)$.

144 Tubes were placed in holes in wooden frames and their position was adjusted before 145 casting of the mortar into cylindrical PVC moulds (diameter $100 \mathrm{~mm}$, height $50 \mathrm{~mm}$ ) as 
146 illustrated in Figure 1. After casting, the samples were stored in an air-conditioned room

$147(20 \circ \mathrm{C}, 95 \% \mathrm{RH})$ and demoulded after 24 hours. Subsequently, they were cured at room

148 temperature $(20 \circ \mathrm{C}, 60 \% \mathrm{RH})$ during 14 days until testing.

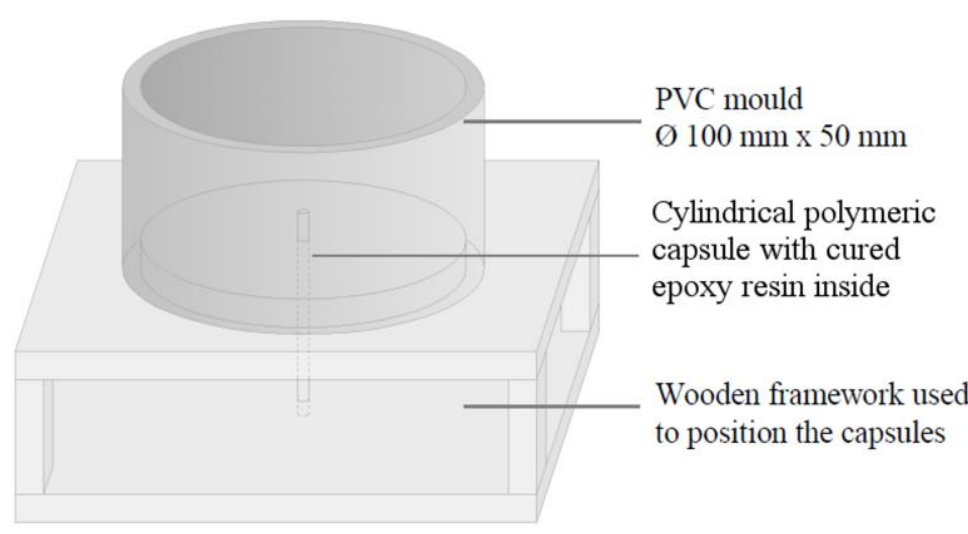

151 Figure 1: Moulds used to prepare the mortar samples with the embedded capsules for

152 the bond strength tests (redrafted after [13]).

153

154 In order to quantify the ability of the capsules to break at the moment of crack formation,

155 mortar specimens containing capsules were prepared. Mortar mixtures consisted of $1561350 \mathrm{~g}$ DIN standard sand, $450 \mathrm{~g}$ binder and $180 \mathrm{~g}$ water $(\mathrm{W} / \mathrm{C}=0.4)$. They were

157 prepared according to the standard NBN EN 196-1 (2005).

158 First, a layer of $10 \mathrm{~mm}$ mortar was poured into $40 \mathrm{~mm}$ x $40 \mathrm{~mm}$ x $160 \mathrm{~mm}$ moulds. Two 159 steel reinforcing bars with a diameter of $2 \mathrm{~mm}$ were placed on top of the mortar layer to 160 avoid premature failure during crack formation. Two to four capsules were positioned in 161 the middle of the specimen where the crack was presumed to appear as illustrated in 162 Figure 2 before filling the mould completely. 


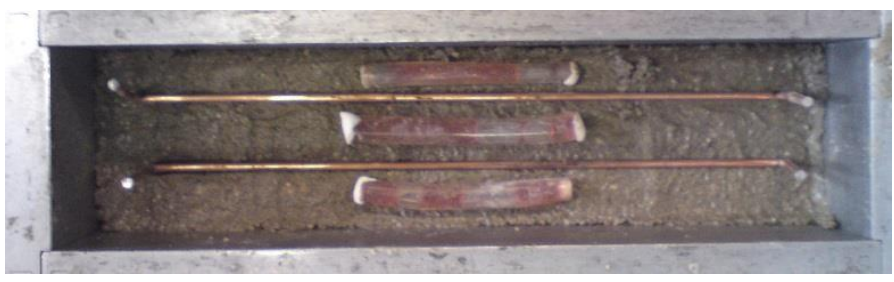

165 Figure 2: Preparation of mortar prisms with embedded capsules and reinforcement.

167 PS, PLA and P(MMA/n-BMA) capsules were placed in the mortar specimens. As 168 illustrated in Table 3, some capsules which survived mixing were embedded, as well as 'new' capsules which were not mixed previously.

170 Table 3: Capsules embedded in mortar specimens.

\begin{tabular}{|c|c|c|c|c|c|}
\hline Specimen & Polymer & $\begin{array}{c}\text { Number of } \\
\text { specimens }\end{array}$ & $\begin{array}{c}\text { Number of } \\
\text { capsules per } \\
\text { specimen }\end{array}$ & $\begin{array}{c}\text { Already mixed } \\
\text { hot (MH), or } \\
\text { cold (MC), and } \\
\text { eventually } \\
\text { deformed (D), } \\
\text { or new (N) }\end{array}$ & $\begin{array}{c}\text { Approximate } \\
\text { ize (range of } \\
\text { size, cf Table } \\
2)\end{array}$ \\
\hline PBS3MH & P(MMA/n-BMA) & 2 & 3 & MH & S3 \\
\hline PBS1MH & P(MMA/n-BMA) & 2 & 3 & MH & S1 \\
\hline PBS3MHD & P(MMA/n-BMA) & 2 & 3 & MH \& D & S3 \\
\hline PBS3N & P(MMA/n-BMA) & 2 & 4 & N & S3,S4 \\
\hline PLAS3MC & PLA & 1 & 4 & MC & S3 \\
\hline PLAS2MH & PLA & 2 & 4 & MH & S2 \\
\hline PLAS1MH & PLA & 2 & 4 & MH & S1 \\
\hline PLAS1N & PLA & 2 & 4 & N & S1 \\
\hline PSN & PS & 2 & 2 & N & \\
\hline PSMC & PS & 2 & 2 & MC & \\
\hline PSMH & PS & 2 & 2 & MH & \\
\hline
\end{tabular}

\subsection{Experimental methods}

\section{$173 \quad$ 2.2.1 Tensile tests and quantification of the resistance in cement slurry}

174 Tubes with a length of $10 \mathrm{~cm}$ were cut from the hollow tubes. They were filled with

175 epoxy the first $4 \mathrm{~cm}$ from both ends in order to centralize the rupture in the $2 \mathrm{~cm}$ length

176 central part. To quantify the influence of a possible degradation of the polymer capsule

177 in a high $\mathrm{pH}$ environment, some tubes were immersed during 7 or 14 days in cement

178 slurry with a water to cement ratio of $10(\mathrm{pH}$ between 12.5 and 13$)$, before performance

179 of the tensile tests. Then, nuts were glued at the end of the tubes with epoxy resin. The 
180 nuts and the parts of the tubes filled with epoxy resin were covered by epoxy paste to

181 avoid slippage. Screws were introduced into the nuts and linked to the apparatus with a 182 ball-and-socket joint as illustrated in Figure 3.

183

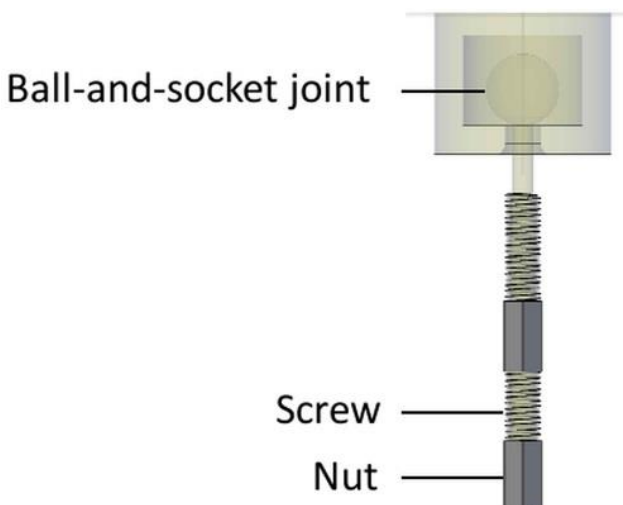

Polymeric capsule

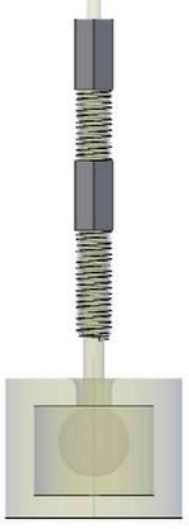

185 Figure 3: Test setup used to determine the tensile strength of the polymeric capsules.

187 A displacement controlled tensile test was executed at a speed of $2 \mathrm{~mm} / \mathrm{min}$. Five 188 repetitions were provided for each polymer type. After breakage of the tubes, the cross189 section was measured for each tube end by means of a light microscope so the tensile 190 strength $\sigma_{\mathrm{t}}$ and the elongation at rupture $\varepsilon \%$ could be calculated. 
193 Before the test, a nut was glued to the tube to one end, and the other end was $10 \mathrm{~mm}$

194 embedded into the mortar. For the test, the mortar cylinder was fixed in a metallic frame 195 and the screw thread placed in the nut was connected to the apparatus. The loading rate

196 was fixed at a value of $2 \mathrm{~mm} / \mathrm{min}$. For each polymer, 4 or 5 repetitions were provided.

197 The bond strength could be calculated from the measured load according to equation 1

$198[13,41]$.

$$
\tau=\frac{F_{p}}{\pi \times d \times l}
$$

199 Where $\tau$ is the bond strength $\left[\mathrm{N} / \mathrm{mm}^{2}\right], \mathrm{F}_{\mathrm{p}}$ is the force measured when the tube is pulled-

200 out (or maximum force if the tube is not completely pulled-out) [N], $d$ is the tube outer 201 diameter [mm] and 1 is the embedded length of the tube [mm].

\subsubsection{Differential Scanning Calorimetry}

204 In order to determine accurately the glass transition temperature $\left(\mathrm{T}_{\mathrm{g}}\right)$ of the polymers, 205 differential scanning calorimetry (DSC) was performed.

\subsubsection{Dynamic Mechanical Analysis}

208 DMA was performed to investigate the evolution of the storage modulus $\left(\mathrm{E}^{\prime}\right)$, the loss modulus $\left(\mathrm{E}^{\prime \prime}\right)$ and the damping (which is the ratio of $\mathrm{E}^{\prime \prime} / \mathrm{E}^{\prime}$ ) within a temperature range of $20^{\circ} \mathrm{C}-120^{\circ} \mathrm{C}$. Plastic rods with a diameter of $1.8 \mathrm{~mm}$ and $4.9 \mathrm{~mm}$ were extruded and placed in a Mettler-Toledo DMA/SDTA861e machine. A sinusoidal load was applied in the centre of the sample while both sides were fixed. The response is measured by a linear variable differential transformer (LVDT) and the temperature of

214 the sample is measured by a thin metallic wire. 
217 As the capsules must preserve the healing agent until the appearance of cracks, the

218 compatibility with the healing agent was investigated. After sealing the capsules at one

219 side with fast curing MMA glue (X60, HBM, Germany), 5 capsules of each type of

220 polymeric material were filled with a pre-polymer of polyurethane (PU) which cures in

221 contact with water and 5 capsules were filled with water and accelerator (10\% of

222 accelerator for Meyco MP 355 1K) [4]. After sealing the other side with MMA glue, the

223 visual aspect of the capsules was controlled regularly during 14 days: after 1, 2, 5, 10

224 and 14 days to observe any eventual healing agent colour change which could indicate

225 premature hardening.

226

$227 \quad$ 2.2.6 Mixing tests

228 In order to prove the efficiency of adjusting the brittleness of polymeric capsules with temperature, mixing tests have been performed to compare the resistance of capsules at room temperature and heated capsules. Hollow tubes with a length of $5 \mathrm{~cm}$ were used as capsules. After sealing one end with MMA (X60, HBM, Germany), capsules were filled

232 with water mixed with red dye (in order to visualize capsule breakage), and finally sealed at the other end. For the 'hot' concrete mixing test, capsules were heated in an oven during 20 to 40 minutes before the mixing test. The composition of the concrete mixes is detailed in Table 4 and the mixing processes are summarized in Figure 4.

241 Table 4: Concrete composition for mixing tests. 


\begin{tabular}{|c|c|c|c|}
\hline Components & $\begin{array}{c}\text { 'Cold' mix } \\
\text { (for } 101 \text { of concrete) }\end{array}$ & $\begin{array}{c}\text { 'Hot' mix PLA or } \\
\text { P(MMA/n-BMA) }\end{array}$ & 'Hot' mix PS \\
\hline Sand & $6.64 \mathrm{~kg}$ & $6.64 \mathrm{~kg}\left(\right.$ at $\left.80{ }^{\circ} \mathrm{C}\right)$ & $6.64 \mathrm{~kg}\left(\right.$ at $\left.105^{\circ} \mathrm{C}\right)$ \\
\hline Crushed stones $2 / 6$ & $4.50 \mathrm{~kg}$ & $4.50 \mathrm{~kg}\left(\right.$ at $\left.80{ }^{\circ} \mathrm{C}\right)$ & $4.50 \mathrm{~kg}\left(\right.$ at $\left.105^{\circ} \mathrm{C}\right)$ \\
\hline Crushed stones $6 / 20$ & $7.60 \mathrm{~kg}$ & $7.60 \mathrm{~kg}\left(\right.$ at $\left.80{ }^{\circ} \mathrm{C}\right)$ & $7.60 \mathrm{~kg}\left(\right.$ at $\left.105{ }^{\circ} \mathrm{C}\right)$ \\
\hline Cem I 52.5 N & $3.50 \mathrm{~kg}$ & $0 \mathrm{~kg}$ & $0 \mathrm{~kg}$ \\
\hline Water & 1.651 & $1.651\left(\right.$ at $\left.100{ }^{\circ} \mathrm{C}\right)$ & $1.651\left(\right.$ at $\left.100^{\circ} \mathrm{C}\right)$ \\
\hline Capsules & 10 & $10\left(\right.$ at $\left.85^{\circ} \mathrm{C}-100{ }^{\circ} \mathrm{C}\right)$ & $10\left(\right.$ at $\left.120^{\circ} \mathrm{C}\right)$ \\
\hline
\end{tabular}

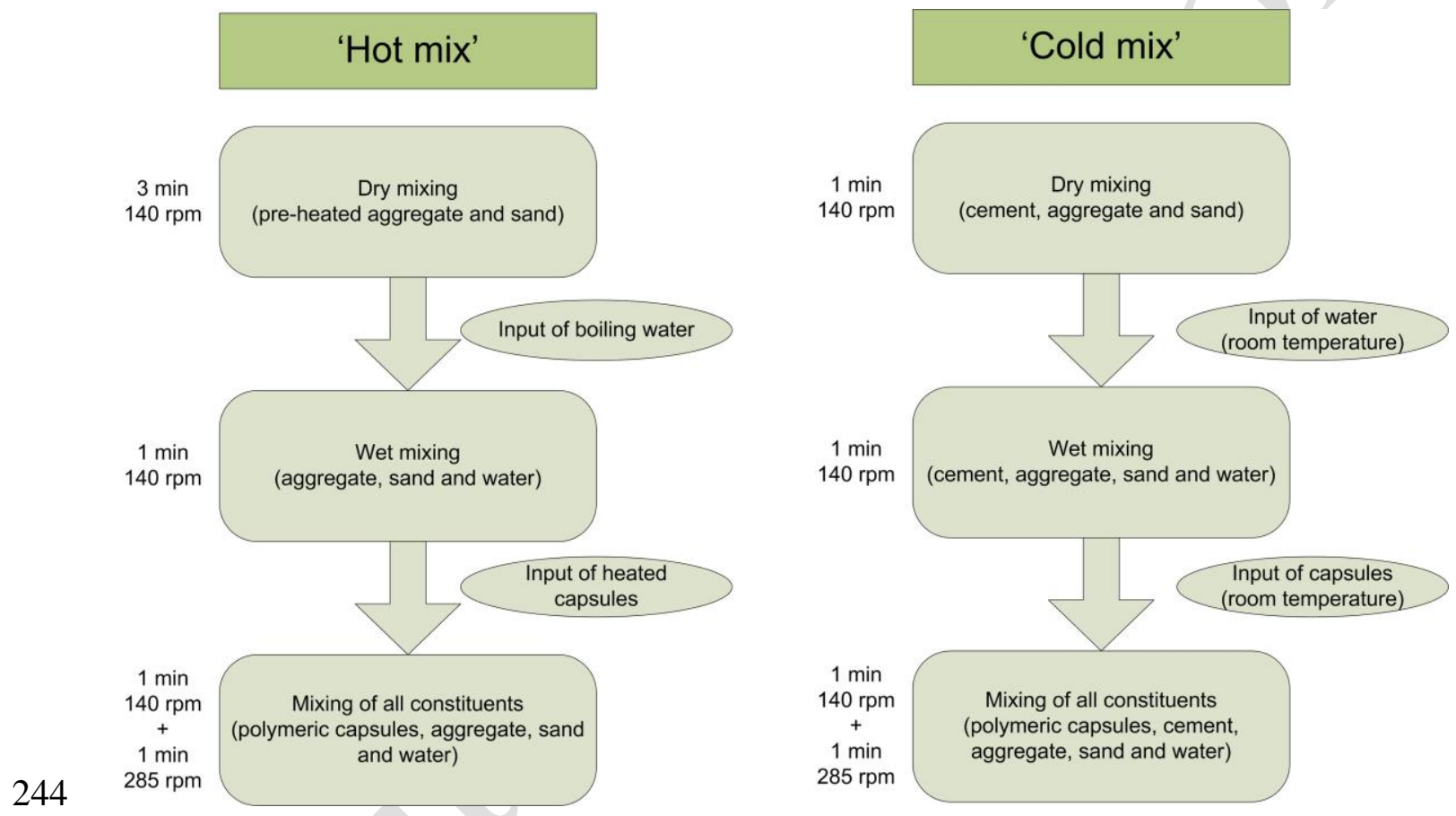

245 Figure 4: Mixing processes used to study the influence of the temperature on the

246 resistance of the capsules.

248 First, the dry components (aggregates, sand, cement) with a temperature of around

$24920{ }^{\circ} \mathrm{C}$ were mixed, in an Hobart type D-300 mixer, at a speed of 140 revolutions per

250 minute during 1 min for 'cold' mixing. For 'hot' mixing, pre-warmed aggregates and

251 sand (at a temperature decided according to the $T_{g}$ of the polymeric capsule) were

252 mixed at a speed of 140 revolutions per minute in an initially cold mixer during 
approximately 3 minutes (delay is due to the transportation of the heated capsules).

254 Then, water (boiling water for hot mixes) was added and mixed for 1 minute at the same speed. Subsequently, for 'cold' and 'hot' mixes, capsules were thrown in the mix without stopping the mixer. For 'hot' mixes, the added capsules were pre-heated. Their temperature was between $85^{\circ} \mathrm{C}$ and $100{ }^{\circ} \mathrm{C}$ for PLA and $\mathrm{P}(\mathrm{MMA} / \mathrm{n}-\mathrm{BMA})$ because they were transported in boiling water between the oven $\left(\right.$ at $85^{\circ} \mathrm{C}$ ) and the mixer, and around $120{ }^{\circ} \mathrm{C}$ for PS capsules which were transported in around 1 minute between the oven (at $140{ }^{\circ} \mathrm{C} . \mathrm{C}$ ) and the mixer wrapped in paper and held in heat resistant gloves. The 'hot' mix was performed without cement in order to avoid premature hardening of the cement. Capsules were mixed with the other ingredients for 1 minute at a speed of 140 revolutions per minute and for 1 minute at a speed of 285 revolutions per minute.

\subsubsection{Three-point-bending test with mortar specimens containing capsules}

To measure the crack width during the three-point-bending test a linear variable differential transformer (LVDT, Solartron AX/0.5/S) was used. This LVDT had a measurement range of $\pm 500 \mu \mathrm{m}$ and an accuracy of $1 \mu \mathrm{m}$. A walter + bai ag Testing machine $(15 \mathrm{kN}-250 \mathrm{kN})$ was used to perform the three-point-bending test. Two different test methods were used. The first method was used to see if the capsules break when a crack is created and its width increases at a speed of $0.001 \mathrm{~mm} / \mathrm{s}$ until $0.4 \mathrm{~mm}$ (measured by LVDT) after 14 days of curing. Capsule breakage was expected and some

273 pictures were taken when leaching dye of the broken capsules was detected (water mark 274 on the concrete surface). In the second method the mortar sample was completely broken to see whether the capsules break or whether they slip. The second method was applied 1 day after the first method in case the capsules were not broken during the first

277 method. It consisted of a load controlled bending test (without the LVDT). The load 
278 was increased with a speed of $0.1 \mathrm{kN} / \mathrm{s}$. Because the rupture of a specimen was

279 relatively fast, some pauses (30 seconds) were used to see whether the capsules were 280 broken or not.

\section{3. Results and discussion}

\section{$283 \quad 3.1$ Tensile tests and quantification of the resistance in cement slurry}

284 The tensile strength of PLA seems to be the highest according to Figure 5 but results must be nuanced.

286 The measured tensile strength of PLA (around $60 \mathrm{~N} / \mathrm{mm}^{2}$ ) meets the values reported in 287 literature [28]. For PS capsules, the tensile strength is underestimated as the PS tubes 288 broke inside the epoxy resin, which was situated between the capsule and the nut 289 represented Fig. 3, or the epoxy resin slipped. Tabulated values of PS tensile strength 290 are around $50 \mathrm{~N} / \mathrm{mm}^{2}$ [42] i.e. twice as high as the measured values. For P(MMA/n291 BMA), breakage occurred at the interface between the epoxy resin and the tube. So the 292 tensile strength should be higher than the obtained values. Therefore, P(MMA/n-BMA) 293 probably has the lowest tensile strength of around 10 to $20 \mathrm{~N} / \mathrm{mm}^{2}$.

294 For all polymers, the measured tensile strength is higher than the tensile strength of 295 cementitious materials $\left(5 \mathrm{~N} / \mathrm{mm}^{2}\right)$ and the one of PLA is close to the one reported by 296 Van Tittelboom for glass capsules (around $60 \mathrm{~N} / \mathrm{mm}^{2}$ ) [13].

297 Exposure of the capsules to an alkaline environment for 7 or 14 days does not result in 298 an significant difference in tensile strength for PLA and PS according to a one-way 299 ANOVA. However there is a significant difference (significance level of 0.01) for $300 \mathrm{P}(\mathrm{MMA} / \mathrm{n}-\mathrm{BMA})$ as tensile strength of capsules placed in filtered cement slurry show a 301 lower tensile strength. 


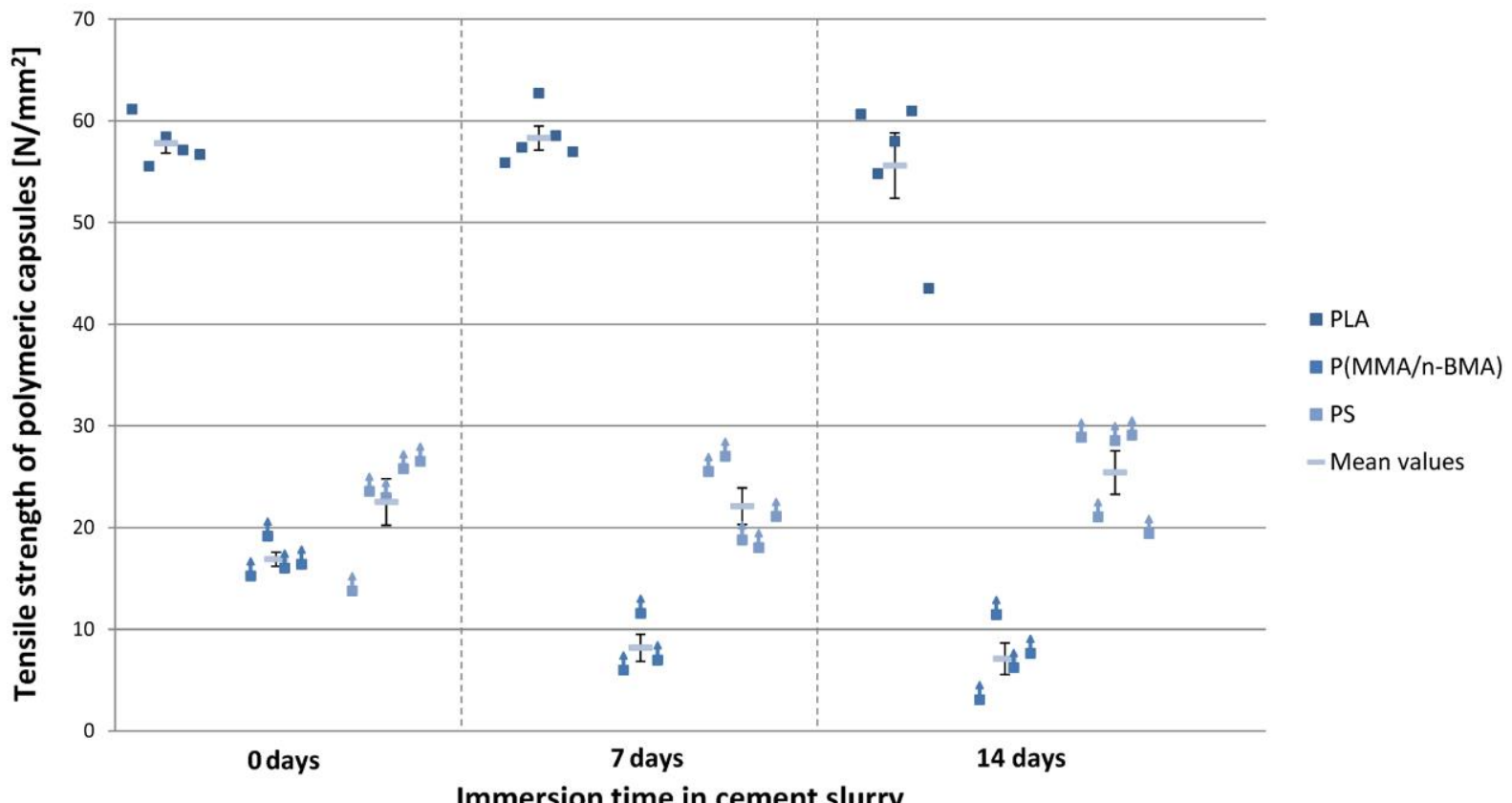

305 Figure 5: Individual values (squares) and mean values (horizontal lines) with standard

306 error of the tensile strength of the polymeric capsules (upward arrows indicate that the

307 values should be higher) versus immersion time in cement slurry.

309 The recorded elongation can also be analysed to compare the elongation at rupture as

310 illustrated in Figure 6. All the elongations at rupture were between $0.5 \mathrm{~mm}$ and $2 \mathrm{~mm}$

311 which should represent $2.5 \%$ to $10 \%$ considering only that the $20 \mathrm{~mm}$ unfilled part of

312 the tube can deform (but these values have to be nuanced as some breakage did not

313 occur in the centre part and some samples have slipped in the epoxy resin). The smallest

314 elongations have been registered for P(MMA/n-BMA) $(2 \%-4 \%)$ while PS and PLA

315 seem to have almost the same behaviour (elongations between $4 \%$ and $10 \%$ ). This

316 could indicate that $\mathrm{P}(\mathrm{MMA} / \mathrm{n}-\mathrm{BMA})$ is the most brittle material tested among the 3

317 polymers. Exposure to high $\mathrm{pH}$ during 7 days and 14 days does not influence the

318 brittleness of PS and P(MMA/n-BMA). For PLA, elongations are significantly lower

319 after 7 days in filtered cement slurry (significance level of 0.05). Considering the high 
320 value of the standard error at 14 days, no conclusion can be drawn about the influence

321 of alkaline environment on elongation at breakage of PLA.

322

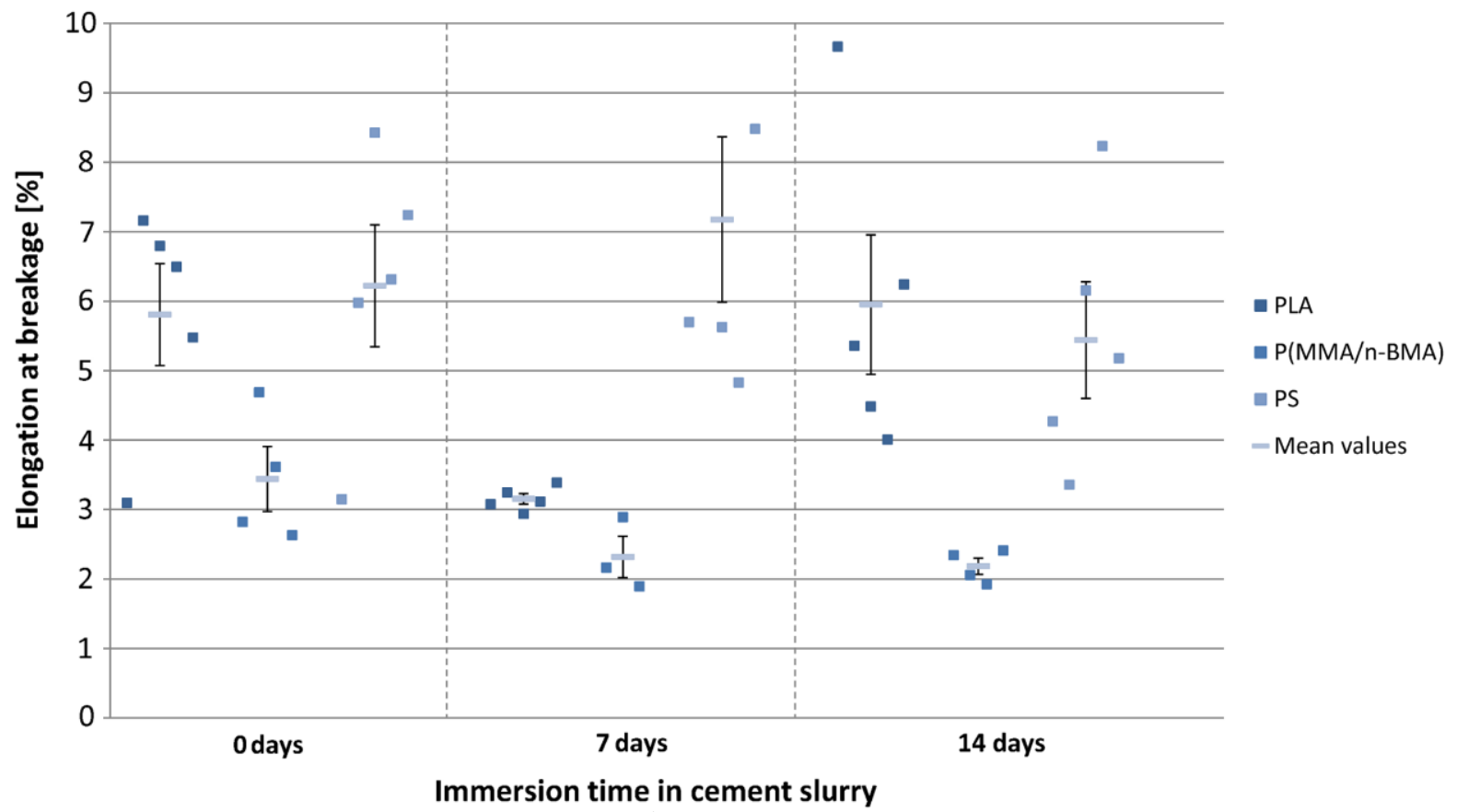

323

324 Figure 6: Individual values (squares) and mean values (horizontal lines) with standard

325 error of the elongation at rupture of the polymeric capsules versus immersion time in cement slurry.

\subsection{Bond strength tests}

329 For several capsules (especially the ones with a small diameter and wall thickness

330 (PLA)), failure was caused by breakage of the capsules and slippage between the epoxy

331 (the resin holding the nut and screw thread linked to the test bench or the glue inside the

332 capsule) and the polymeric capsules (probably after breakage of polymeric capsules).

333 For these samples, the bond strength should be higher than the reported value. As

334 illustrated in Figure 7, the bond strength between PS capsules and mortar is the best one

335 with an average value around $3.5 \mathrm{~N} / \mathrm{mm}^{2}$. This value is higher than the ones reported

336 [13] for glass (between $0.2 \mathrm{~N} / \mathrm{mm}^{2}$ and $1 \mathrm{~N} / \mathrm{mm}^{2}$ ) and ceramic (average value around 
$\left.3373 \mathrm{~N} / \mathrm{mm}^{2}\right)$. The bond strengths between PLA or P(MMA/n-BMA) and the cementitious

338 matrix are close to the one between glass and the cementitious matrix.

339

340

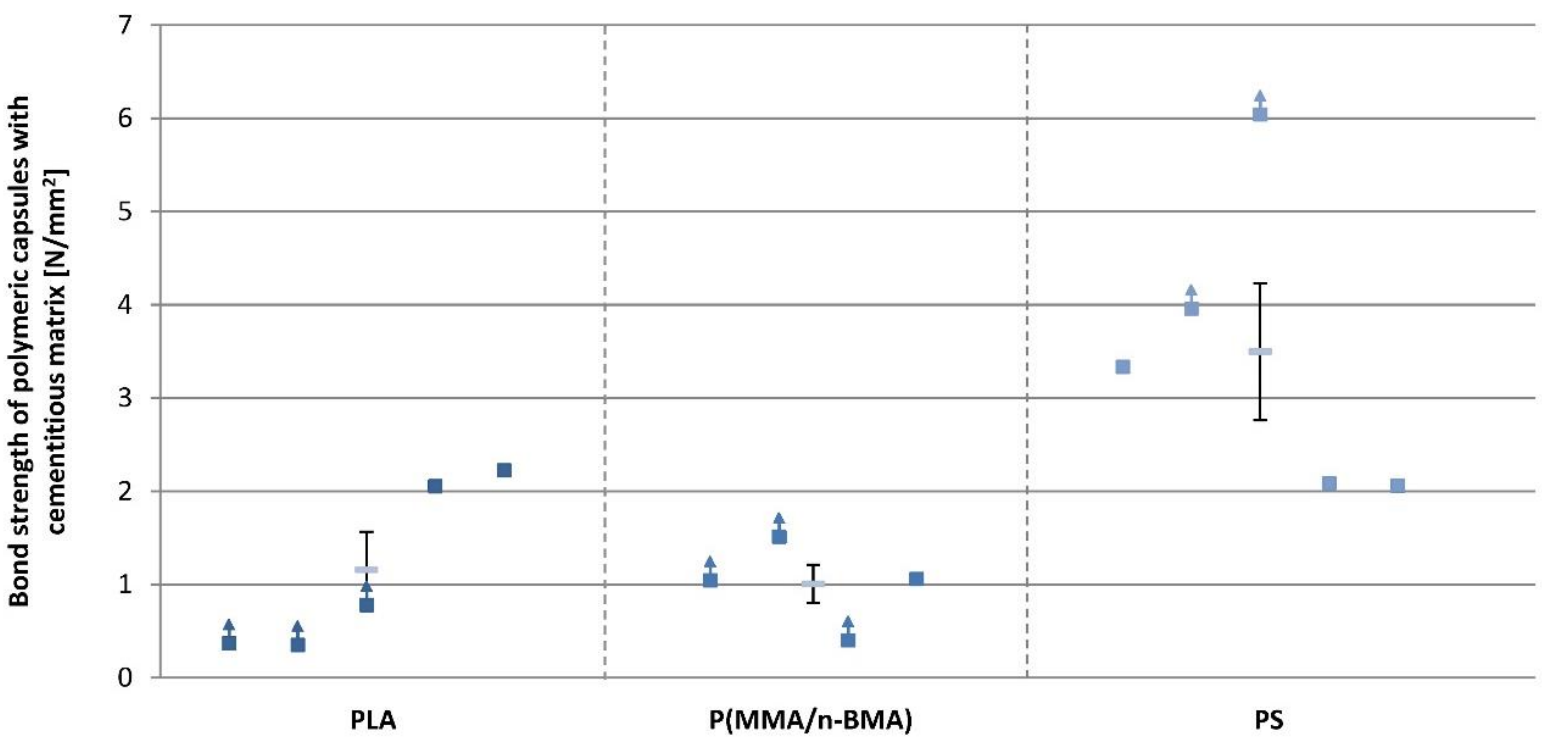

341 Figure 7: Individual values (squares) and mean values (horizontal lines) with standard

342 error of bond strength between polymeric capsules and cementitious matrix (upward 343 arrows indicate that values should be higher because failure was not caused by bond 344 loss).

\subsection{Differential Scanning Calorimetry}

347 From the DSC measurements, it results that the $\mathrm{T}_{g}$ of PLA and P(MMA/n-BMA) is around $60^{\circ} \mathrm{C}$. Concerning $\mathrm{P}(\mathrm{MMA} / \mathrm{n}-\mathrm{BMA})$, this is more than the expected value of

$34950{ }^{\circ} \mathrm{C}$ announced by the supplier. For PS, the measured $\mathrm{T}_{\mathrm{g}}$ is of around $102{ }^{\circ} \mathrm{C}$. These

350 values are relatively high compared to the initial investigated range of glass transition

351 temperatures between $35^{\circ} \mathrm{C}$ and $50{ }^{\circ} \mathrm{C}$ but are reasonable for PLA and P(MMA/n-BMA)

352 regarding their low cost. 


\subsection{Dynamic Mechanical Analysis}

356 The main interest of DMA for this study is to investigate the evolution of the

357 mechanical behaviour of capsules with temperature. Therefore, the storage modulus (E')

358 is the most relevant parameter as, with increasing temperature, it drops around the $\mathrm{T}_{\mathrm{g}}$

359 emphasizing the transition from a brittle behaviour (with a high storage modulus) to a

360 rubbery state (with a lower storage modulus). As illustrated in Figure 8, for the three

361 polymers, $E^{\prime}$ drops from a value around $1000 \mathrm{MPa}$ to a value around $10 \mathrm{MPa}$. For PLA

362 the drop in $\mathrm{E}^{\prime}$ occurs between $52^{\circ} \mathrm{C}$ and $67^{\circ} \mathrm{C}$, for $\mathrm{P}(\mathrm{MMA} / \mathrm{n}-\mathrm{BMA})$ between $55^{\circ} \mathrm{C}$

363 and $80{ }^{\circ} \mathrm{C}$ and for PS between $95^{\circ} \mathrm{C}$ and $115^{\circ} \mathrm{C}$.

364 In order to increase the survival ratio of capsules during mixing, one has to heat the

365 capsules at least around the temperature corresponding to the end of the drop of storage

366 modulus: $67{ }^{\circ} \mathrm{C}$ for PLA, $80{ }^{\circ} \mathrm{C}$ for P(MMA/n-BMA) and $115^{\circ} \mathrm{C}$ for PS.

367

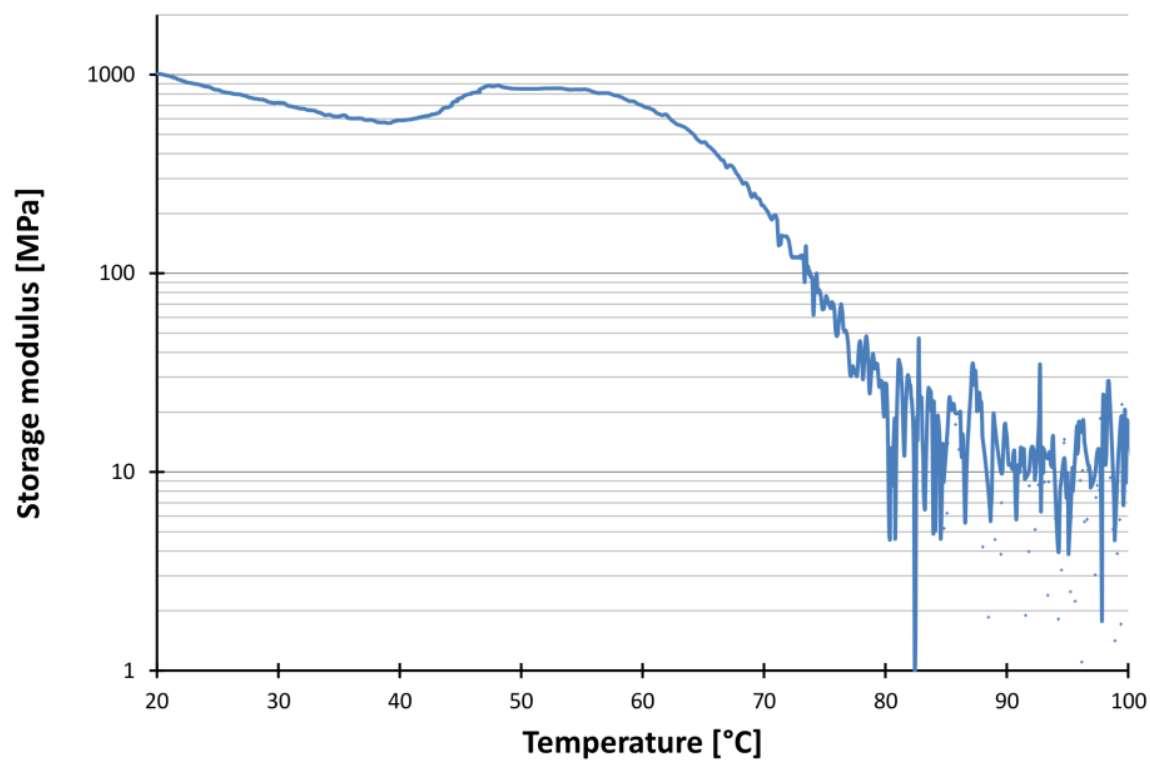

Figure 8: Evolution of the storage modulus of $\mathrm{P}(\mathrm{MMA} / \mathrm{n}-\mathrm{BMA})$ between $20{ }^{\circ} \mathrm{C}$ and $100{ }^{\circ} \mathrm{C}$. 


\section{3.5. Compatibility with healing agent}

373 Pictures of the capsules, taken regularly during 14 days after injection of the healing 374 agent, revealed that the polyurethane pre-polymer hardens in the polymeric capsules.

375 However, the speed of hardening seems different for the 3 polymers. First hardening 376 signs have been observed after 5 days for P(MMA/n-BMA) capsules and after 4 days

377 for PLA capsules, while hardening started after 10 days in PS capsules (and no white 378 deposits were observed, only a global change in colour was noticeable). Even after 3 379 weeks PU was not completely hard in PS capsules when 2 capsules were cut. This 380 curing of the pre-polymer is probably due to a lack of permeability of the studied

381 polymeric capsules or a possible reaction between the pre-polymer and the capsule. All

382 these times of curing are still much too fast to be applicable in self-healing concrete and 383 the shelf-life of the capsules must be increased.

384

385 3.6. Mixing tests

386 At the end of the mixing test, entire capsules and parts of capsules were found in the 387 concrete mix. The survival ratios are reported in Figure 9. 


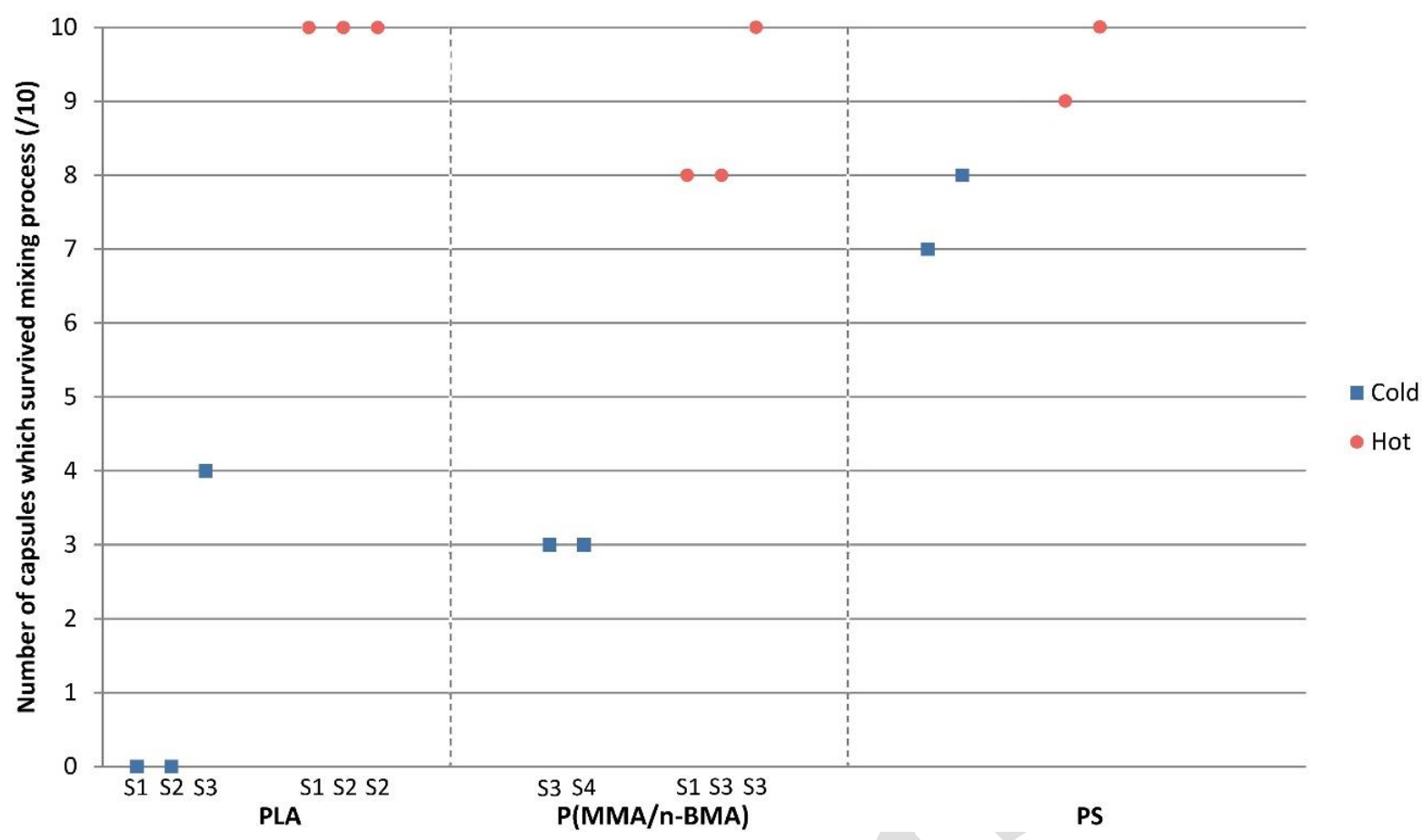

390 Figure 9: Survival ratio of polymeric capsules during cold and hot concrete mixing 391 process.

393 The improvement in survival ratio after hot mixing is assumed to be caused by the more

394 flexible behaviour of the capsules above their Tg. For PLA, all the capsules survived the 395 hot mixing process, even the very small ones with a wall thickness around $0.4-0.5 \mathrm{~mm}$

396 (S1 see Table 5) whereas none survived the cold mixing process. For P(MMA/n-BMA), 397 capsules had bigger dimensions so that could explain the slightly higher cold survival 398 ratio. The capsules heated during 1 hour were flat and the wall thickness a little bit 399 smaller maybe due to thermal expansion before mixing (as illustrated in Figure 10, the 400 capsule is larger close to the sealing MMA glue) inducing a different resistance due to 401 their new shape whereas the capsules heated only 30 minutes conserved their cylindrical 402 shape and all survived the mixing test. PS capsules were initially the ones with the 403 biggest diameter and wall thickness. Therefore it is supposed that this is the reason why 404 they survived the cold mixing process rather well. The improvement between the cold 
and hot mixing process for PS capsules is noticeable even if it is not sure the capsules temperature remained above their $\mathrm{T}_{\mathrm{g}}\left(102{ }^{\circ} \mathrm{C}\right)$ during all the mixing process as the final

407 temperature of the 'hot concrete' mix has been measured to be around $70{ }^{\circ} \mathrm{C}$.

408

409 Table 5: Three-point-bending test results concerning capsule breakage.

\begin{tabular}{|c|c|c|c|}
\hline Name of specimen & $\begin{array}{c}\text { Number of } \\
\text { broken capsules }\end{array}$ & $\begin{array}{c}\text { Crack width when } \\
\text { breakage [mm] }\end{array}$ & Dye visible \\
\hline PBS3MH & 2 & $0.142,0.347$ & No \\
\hline PBS1MH & 1 & 0.300 & Yes \\
\hline PBS3MHD & 5 & $\begin{array}{c}0.080,0.120,0.270, \\
0.158,0.320\end{array}$ & Yes \\
\hline PBS3N & 0 & & \\
\hline $\begin{array}{c}\text { PLAS3MC, } \\
\text { PLAS2MH, }\end{array}$ & 0 & & \\
\hline PLAS1MH, PLAS1N & 0 & & \\
\hline PSN, PSMC, PSMH & & & \\
\hline
\end{tabular}

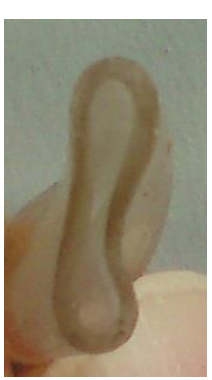

(a)

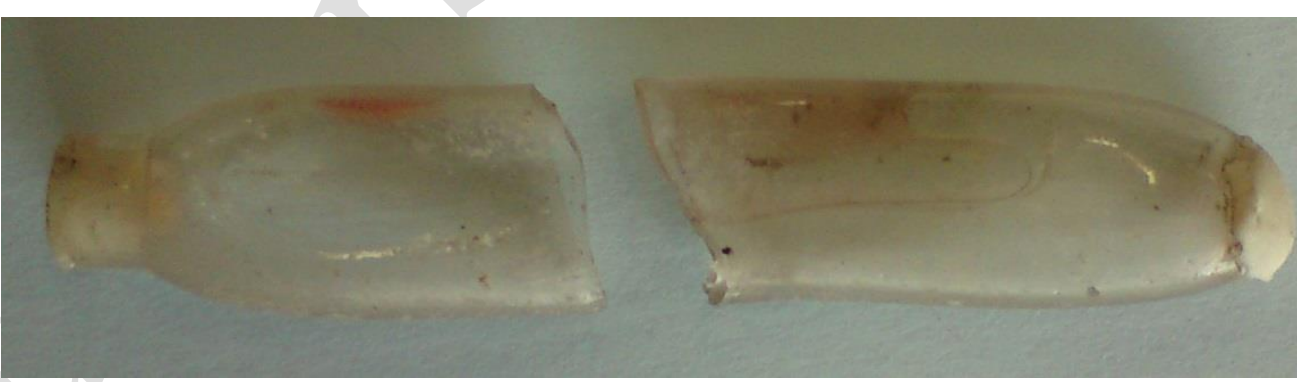

(b)

413 Figure 10: Deformed P(MMA/n-BMA) caused by excessive heating time ((a) cross-

414 section with wall thickness smaller than for straight capsules, (b) side view with visible

415 thermal expansion).

416

417 3.7. Three-point-bending tests with mortar specimens containing capsules

418 The results of the first test for all the capsules are presented in Table 5 with the codes 419 presented in Table 3. 


\subsubsection{Polystyrene and Poly(lactic acid) capsules}

422 None of the PS and PLA capsules broke when cracks with a width of $0.4 \mathrm{~mm}$ were 423 created. No drops were observed on the load curves and no water marks were observed.

424 During the second test, the PS capsules broke without visible slippage when the 425 specimens were completely broken. The fact that PS capsules only broke when the two 426 parts of the specimen were disconnected can be explained by the wall thickness of the capsules. Breakage of the capsules occurred suddenly. Consequently, the brittle behaviour of PS capsules is confirmed. Also the good bond strength of PS capsules with the cementitious matrix is verified as the capsules were not pulled out even if the load was around $6 \mathrm{kN}$.

431 PLA capsules also broke during the second test, but most of them broke just before specimen failure at loads of around $5.5 \mathrm{kN}$. A white colour caused by plastic deformation of the capsules was observed. This explains why the capsules did not break during the first test even though the wall thickness was small (around $0.4 \mathrm{~mm}$ for the smallest ones). Moreover, some small capsules (PLAS1N and PLAS3MC) were pulled out when the two parts of the specimens were disconnected. This indicates that there is unsufficient bond between these PLA capsules and the cementitious matrix.

\subsubsection{Poly(methyl methacrylate/n-butyl methacrylate) capsules}

440 Some P(MMA/n-BMA) capsules broke with crack appearance. For the two specimens 441 with incorporated deformed capsules, which previously survived the hot mixing process, 442 some capsules broke and released the water they initially contained as illustrated in

443 Figure 11. For two other specimens with capsules which previously resisted the 444 concrete mixing process but were not deformed, breakage of capsules was observed. 


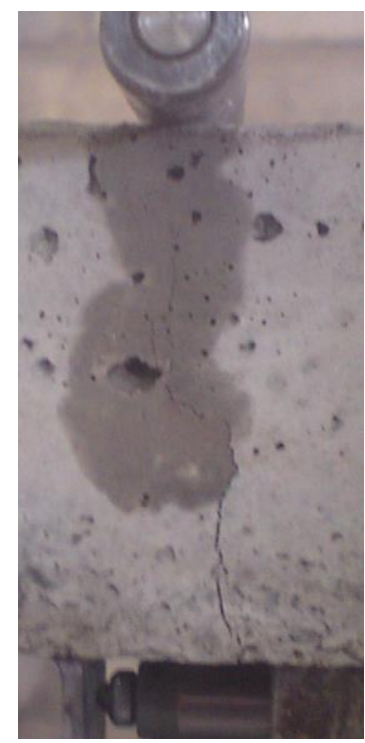

447 Figure 11: Water released because of capsule breakage in the specimen PBS3MHD.

449 The crack width at which the capsules broke was deduced from the graphs representing 450 the load in function of the crack width measured by the LVDT. When a sudden drop in 451 the curve was observed (as illustrated in Figure 12) and the sound of capsule breakage 452 was heard, the capsules were supposed to be broken.

454 Almost all the capsules which were mixed in while heated and which deformed, broke 455 during the three-point-bending test (5/6): 3 capsules broke when the crack width was 456 around $0.15 \mathrm{~mm}$, which corresponds to a relatively small crack. Therefore, if the healing 457 agent could be encapsulated by these capsules, healing of cracks with a width of around $4580.15 \mathrm{~mm}$ could be possible. 2 other capsules broke while the crack width was around $4590.30 \mathrm{~mm}$. None of the P(MMA/n-BMA) capsules which had not been mixed previously, 460 broke during the three-point-bending test. 


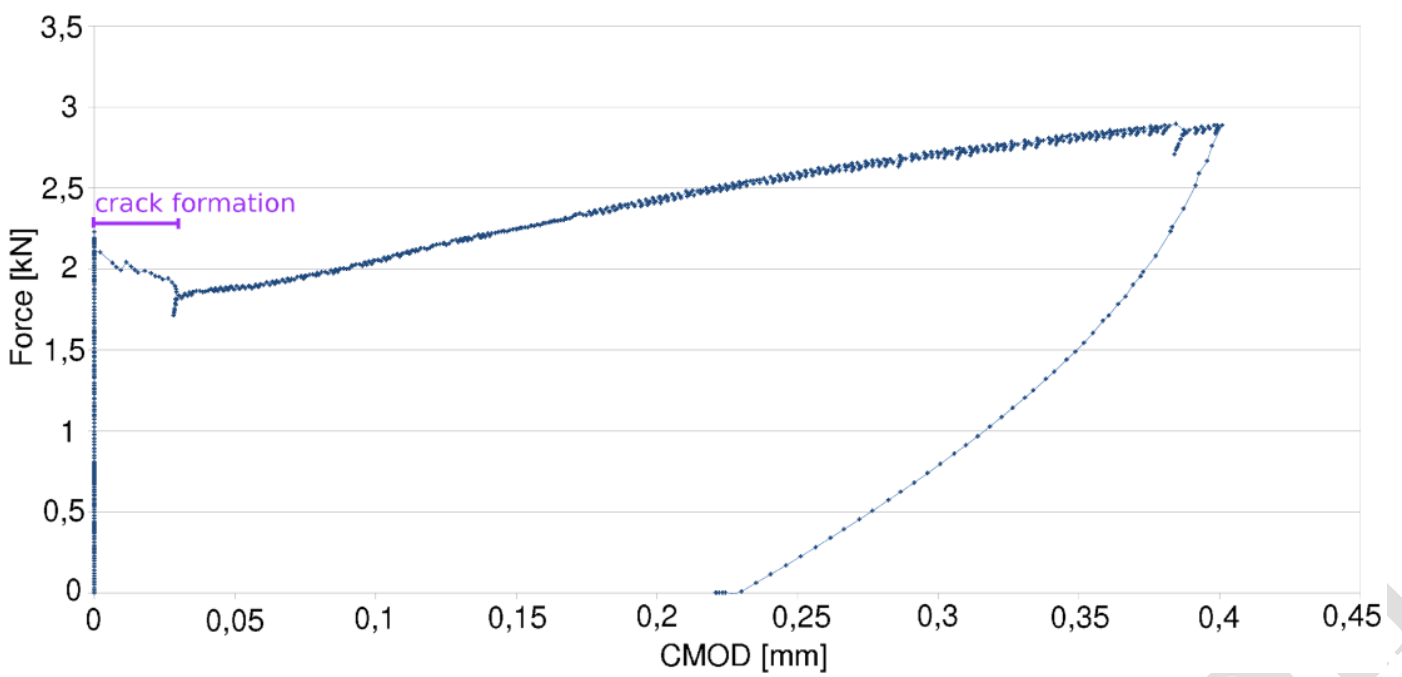

462

(a)

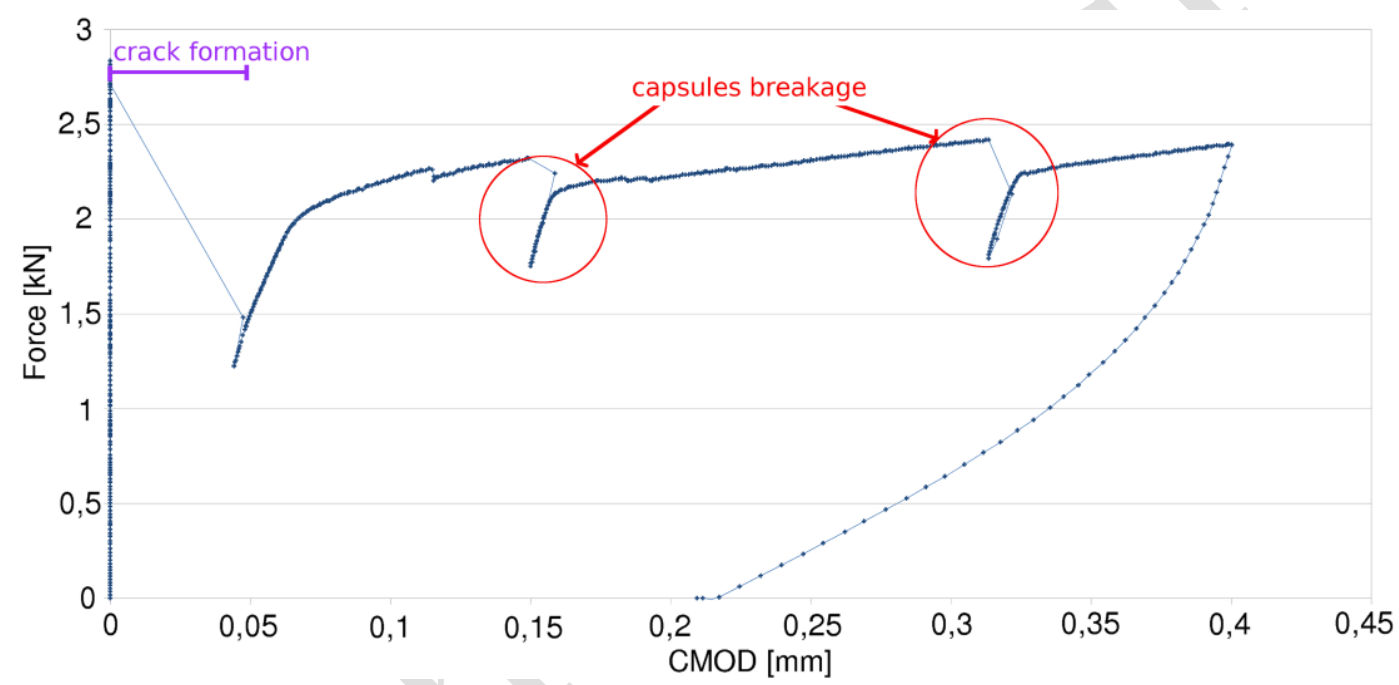

465 (b)

466 Figure 12: Loading curves obtained during the three-point-bending test, (a) without

467 capsules breakage, (b) with capsules breakage (specimen PBS3MHD2)

468

469 The second test confirmed that all the capsules were broken during the first test for one

470 of the two specimens (PBS3MHD) as the capsules were empty. For the other specimen

471 (PBS3MHD) containing deformed capsules, one capsule broke when the load was

472 around $4 \mathrm{kN}$ releasing the water it was containing. For the straight $\mathrm{P}(\mathrm{MMA} / \mathrm{n}-\mathrm{BMA})$

473 capsules which survived the hot mixing process, all the capsules which did not break 
474 during the first test, broke during the second test before specimen failure at loads around $4753.5-4.5 \mathrm{kN}$ (pauses were made every $1 \mathrm{kN}$ to check if water marks appeared). For the $476 \mathrm{P}(\mathrm{MMA} / \mathrm{n}-\mathrm{BMA})$ capsules which had not been mixed with concrete, breakage occurred 477 at higher loads around $5 \mathrm{kN}$ and even sometimes at the moment of complete specimen 478 failure. These results demonstrate that the chance of capsules breakage is higher when 479 the capsules have been previously mixed in (and probably damaged, as, in certain cases 480 visible precracking was noticed).

481 The results obtained during the three-point-bending test confirmed the first trends 482 observed with the tensile and bond strength tests:

483 - The P(MMA/n-BMA) capsules are the most brittle ones and they can break when they 484 are subjected to relatively small deformations as in the case when a crack appears,

485 - The bond of all the capsules with the cementitious matrix, except the smallest PLA 486 capsules, seems sufficient to avoid pull out of the capsules. Therefore, the majority of the capsules broke during the three-point-bending test (at least during the second test). The P(MMA/n-BMA) capsules are the only ones which broke at the moment of crack appearance. This indicates that the brittleness of the polymeric capsules has to be as

490 high as possible. PS is known for its brittleness, but the capsules extruded in this study were probably too thick to break. Therefore, besides the brittleness, the shape of the capsules plays an important role. After complete breakage of the specimens, the thickness of the broken $\mathrm{P}(\mathrm{MMA} / \mathrm{n}-\mathrm{BMA})$ capsules was measured. It revealed what was 494 expected after the mixing test: the wall thickness of the deformed capsules is lower than 495 the thickness of the straight capsules. This difference in thickness of the capsules which 496 survived the mixing process is probably the cause of the better breakage efficiency of 497 the deformed capsules. 


\section{4. Conclusions and perspectives}

501 The use of polymeric capsules to obtain self-healing properties in concrete seems

502 promising. In this study, it was investigated whether brittle thermoplastics can resist the

503 concrete mixing process through heating, and break with crack appearance at room

504 temperature. The selected polymers P(MMA/n-BMA), PLA and PS show a brittle

505 behaviour at room temperature with an elongation at rupture lower than $10 \%$. Their

506 glass transition temperatures, measured by DSC is relatively low: respectively $59{ }^{\circ} \mathrm{C}$,

$507 \approx 59{ }^{\circ} \mathrm{C}$ and $\approx 102{ }^{\circ} \mathrm{C}$. Tensile strength tests ensured that the tensile strength of these

508 polymeric capsules (10 to $80 \mathrm{~N} / \mathrm{mm}^{2}$ ) is higher than the tensile strength of concrete

$509\left(5 \mathrm{~N} / \mathrm{mm}^{2}\right)$. Bond strength tests revealed that polymeric capsules can have similar bond

510 strength with concrete as glass capsules (around $1 \mathrm{~N} / \mathrm{mm}^{2}$ ). Therefore, it is expected that

511 these capsules will not lower the mechanical properties of concrete when they are

512 embedded inside the matrix. The dynamic mechanical analysis showed a drop in the

513 storage modulus around the $\mathrm{T}_{\mathrm{g}}$ of the 3 polymers. This drop emphasizes an important

514 loss of rigidity occurring along small temperature ranges: between $52{ }^{\circ} \mathrm{C}$ and $67{ }^{\circ} \mathrm{C}$ for

515 PLA, between $55^{\circ} \mathrm{C}$ and $80{ }^{\circ} \mathrm{C}$ for P(MMA/n-BMA) and between $95{ }^{\circ} \mathrm{C}$ and $115{ }^{\circ} \mathrm{C}$ for

516 PS. Therefore, it is possible to adjust accurately the temperature at which capsules have

517 to be heated to obtain the desirable softness and increase the chance to survive the

518 concrete mixing process. The compatibility between polymeric capsules and the two-

519 component polyurethane-based healing agent needs to be improved. The prepolymer of

520 this healing agent starts to harden in the capsules probably because of the air and

521 moisture permeability of the polymers. A combination of glass to protect moisture

522 sensitive healing agent, and thermoplastic to protect glass against mixing could be a

523 possible solution to this problem. The mixing of concrete with incorporated capsules 
524 demonstrated the interest to heat the capsules beforehand. When capsules were mixed at

525 room temperature with aggregates, sand, cement and water, only the ones with an 526 important wall thickness (around $1.6 \mathrm{~mm}$ for PS capsules) resisted the process, 527 exhibiting a high survival ratio (over 8/10). The majority of the capsules with a wall 528 thickness between $0.4 \mathrm{~mm}$ (PLA S1) and $1.5 \mathrm{~mm}$ (P(MMA/n-BMA S3) did not resist 529 the mixing process at room temperature. However, when capsules were heated in a 530 small oven at temperatures above their $\mathrm{T}_{\mathrm{g}}\left(90^{\circ} \mathrm{C}\right.$ for PLA and P(MMA/n-BMA), $531140{ }^{\circ} \mathrm{C}$ for PS) and were mixed with heated aggregates and sand $\left(80^{\circ} \mathrm{C}\right.$ for PLA and $\mathrm{P}(\mathrm{MMA} / \mathrm{n}-\mathrm{BMA}), 105^{\circ} \mathrm{C}$ for PS $)$ and boiling water, almost all the capsules resisted the

533 hot mixing process, even the smallest ones. Some P(MMA/n-BMA) capsules, which

534 previously survived the concrete mixing process, broke with crack appearance during 535 the three-point-bending test. The probability of breakage is linked to the wall thickness 536 of the capsules, their shape and, probably, the damage they suffered during the mixing 537 process because none of the $\mathrm{P}(\mathrm{MMA} / \mathrm{n}-\mathrm{BMA})$ which had not previously mixed in, 538 broke with crack appearance.

539 Although heating capsules prior to mixing seems complicated from an industrial point

540 of view, a deeper characterisation of the polymer degradation over time (increase of the 541 brittleness due to aging) supports the development of time-evolution capsules for 542 industrial applications in the future. The authors believe that polymeric capsules will be 543 useful to replace glass capsules to carry polymeric healing agent for self-healing 544 concrete because they can resist the concrete mixing process. Therefore, the global cost 545 of self-healing concrete will decrease, and the solution could be extended to industry in 546 large-scale concrete structural elements.

\section{Acknowledgments}


549 The authors would like to thank the Polymer Chemistry Research Group (Ghent

550 University) for its technical support to this study.

551

552

553

554

555

556

557

558

559

560

561

562

563

564

565

566

567

568

569

570

571

572

573

\section{References}

[1] E. Cailleux, V. Pollet, Investigations on the development of self-healing properties in protective coatings for concrete and repair mortars, Proceedings of the 2nd International Conference on Self Healing Materials, 2009.

[2] K. van Breugel, Is there a market for self-healing cement-based materials?, Proceedings of the 1st International Conference on Self-Healing Materials, 2007.

[3] S. van der Zwaag, An Introduction to Material Design Principles: Damage Prevention versus Damage Management, Springer, Dordrecht, 2007. p 1-18.

[4] K. Van Tittelboom, N. D. Belie, D. Van Loo, P. Jacobs, Self-healing efficiency of cementitious materials containing tubular capsules filled with healing agent, Cement and Concrete Composites 2011;33 (4):497 - 505.

[5] V. C. Li, Y. M. Lim, Y.-W. Chan, Feasibility study of a passive smart selfhealing cementitious composite, Composites Part B: Engineering 1998;29 (6):819 - 827. [6] C. Dry, Design of self-growing, self-sensing and self-repairing materials for engineering applications, Proceedings of the society of photo-optical instrumentation engineers, 2001, p. 23-29. [7]
C. Joseph,
A. Jefferson,
B. Isaacs,
R. Lark,
D. Gardner, Experimental investigation of adhesive-based self-healing of cementitious materials, Magazine of Concrete Research 2010;62:831-843.

[8] C. Dry, Matrix cracking repair and filling using active and passive modes for smart timed release of chemicals from fibers into cement matrices, Smart Materials \& Structures 1994;3:118-123. 
575 internal delivery system for smart responsive concrete, Smart Materials and Structures 1996;5 (3):297.

577 [10] C. Dry, M. Corsaw, A comparison of bending strength between adhesive and

578 steel reinforced concrete with steel only reinforced concrete, Cement and Concrete $579 \quad$ Research 2003;33 (11):1723-1727.

580 [11] J. Wang, K. V. Tittelboom, N. D. Belie, W. Verstraete, Use of silica gel or polyurethane immobilized bacteria for self-healing concrete, Construction and Building Materials 2012;26 (1):532 - 540.

[12] P. Tran Diep, Quasi-brittle self-healing materials : numerical modeling and

584 applications in civil engineering, Ph.D. thesis, National University of Singapore, 2011.

585 [13] K. Van Tittelboom, Self-healing concrete through incorporation of encapsulated bacteria- or polymer-based healing agents, Ph.D. thesis, Ghent University, 2012.

587 [14] C. Dry, Smart earthquake resistant materials (using time released adhesives for 588 damping, stiffening, and deflection control), Proceedings of the 3rd ICIM/ECSSM, 589 1996, p. 958-967.

590 [15] P. Tran Diep, J. Tay, S. Quek, S. Pang, Implementation of self healing in 591 concrete - proof of concept, The IES Journal Part A : Civil \& structural Engineering 2009;2 (2):116-125.

593 [16] C. Dry, Smart multiphase composite materials that repair themselves by a 594 release of liquids that becomes solids.,SPIE Proceedings, Vol. 2189, 1994, p. 62-70.

595 [17] H. Liu, S. Quian, J. Van de Kuilen, W. Gard, M. de Rooij, E. Schlangen, 596 W. Ursem, Self healing of concrete cracks using hollow plant fibers, Proceedings of the 597 2nd International Conference on Self-healing Materials, 2009. 
[18] C. Dry, Smart materials which sense, activate and repair damage; hollow porous

599 fibres in composites release chemicals from fibers for self-healing, damage prevention 600 and /or dynamic control, Proceedings of the 1st European Conference on Smart 601 Structures and Materials, 1992, p. 367-370.

602 [19] D. Janssen, Water encapsulation to initiate self-healing in cementitious materials, 603 Master's thesis, Delt University of Technology, 2011.

604 [20] H. Mihashi, T. Nishiwaki, Y. Kaneko, N. Nishiyama, Development of smart 605 concretes, Proceedings of the 1st FIB Congress, 2002.

606 [21] M. M. Pelletier, R. Brown, A. Shukla, A. Bose, Self-healing concrete with a 607 microencapsulated healing agent, 2010.

608 [22] Z. Yang, J. Hollar, X. He, X. Shi, A self-healing cementitious composite using 609 oil core/silica gel shell microcapsules, Cement and Concrete Composites $610 \quad 2011 ; 33(4): 506-512$.

611 [23] I. Kaltzakorta, E. Erkizia, Silica microcapsules encapsulating epoxy compounds

612 for self-healing cementitious materials, Proceedings of the 3rd International Conference 613 on Self Healing Materials, 2011.

614 [24] X. Feng, N. Zhuo, H. Ningxu, D. Biqin, D. Xuexiao, H. Zhan, Z. Ming, 615 Selfhealing mechanism of a novel cementitious composite using microcapsules, in: 616 Proceedings of the International Conference on Durability of Concrete Structures, 2008.

617 [25] V. Wiktor, H. M. Jonkers, Quantification of crack-healing in novel bacteria618 based self-healing concrete, Cement and Concrete Composites 2011;33 (7):763 - 770.

619 [26] K. Sisomphon, O. Copuroglu, Self healing mortars by using different 620 cementitious materials, Proceedings of the International Conference on advances in 621 construction materials through science and engineering, 2011. 
[27] S. Mookhoek, Novel routes to liquid-based self-healing polymer systems, Ph.D.

623 thesis, Delft University of Technology, 2010.

624 [28] R. Auras, B. Harte, S. Selke, H. R., Mechanical, physical, and barrier properties

625 of poly(lactide) films, Journal of Plastic Film and Sheeting 2003;19:123-135.

626 [29] L. Baoa, J. Dorgan, D. Knauss, S. Hait, N. Oliveira, I. Maruccho, Gas 627 permeation properties of poly(lactic acid) revisited, Journal of Membrane Science $628 \quad 2006 ; 285: 166-172$.

629 [30] H. Lehermeier, J. Dorgan, J. D. Way, Gas permeation properties of poly(lactic 630 acid), Journal of Membrane Science 2001;190:243-251.

631 [31] T. Komatsuka, A. Kusakabe, K. Nagai, Characterization and gas transport 632 properties of poly(lactic acid) blend membranes, Desalination 2008;234:212-220.

633 [32] L. Massey, Permeability Properties of Plastics and Elastomers, Second Edition: 634 A Guide to Packaging and Barrier Materials, Plastics Design Library, 2003.

635 [33] K. Babu, D. Babu, Behaviour of lightweight expanded polystyrene concrete 636 containing silica fume, Cement and Concrete Research 2003;33 (5):755-762.

637 [34] D. S. Babu, K. G. Babu, W. Tiong-Huan, Effect of polystyrene aggregate size on 638 strength and moisture migration characteristics of lightweight concrete, Cement and 639 Concrete Composites 2006;28 (6):520-527.

640 [35] B. Chen, J. Liu, Properties of lightweight expanded polystyrene concrete 641 reinforced with steel fiber, Cement and Concrete Research 2004;34 (7):1259-1263.

642 [36] B. Chen, J. Liu, L.-z. Chen, Experimental study of lightweight expanded 643 polystyrene aggregate concrete containing silica fume and polypropylene fibers, Journal 644 of Shanghai Jiaotong University (Science) 2010;15 (2):129-137.

645 [37] S. Melin, Why are crack paths in concrete and mortar different from those in 646 pmma?, Materials and Structures 1989;22 (1):23-27. 
647 [38] A. Moroka, Basic properties of underwater polymer mortars using waste 648 expanded polystyrene-methyl methacrylate-based binders, in: RILEM International 649 Symposium on Environment-Conscious Materials and Systems for Sustainable 650 Development, 2004.

651 [39] E. Šušteršič, M. Tušar, Zupančič V.A., Rheological and mechanical 652 characterization of waste pmma/ath modified bitumen, Construction and Building 653 Materials 2013;38 (0):119- 125.

654 [40] E. Šušteršič, M. Tušar, Zupančič V.A., Asphalt concrete modification with waste $655 \mathrm{pmma} / \mathrm{ath}$, Materials and Structures 2013:1-8.

656 [41] A. Momayez, M. Ehsani, A. Ramezanianpour, H. Rajaie, Comparison of 657 methods for evaluating bond strength between concrete substrate and repair materials, 658 Cement and Concrete Research 2005;35 (4):748-757.

659 [42] D. Priddy, Kirk-Othmer Encyclopedia of Chemical Technology, Wiley, Ch. 660 Styrene Plastics, 2006. 